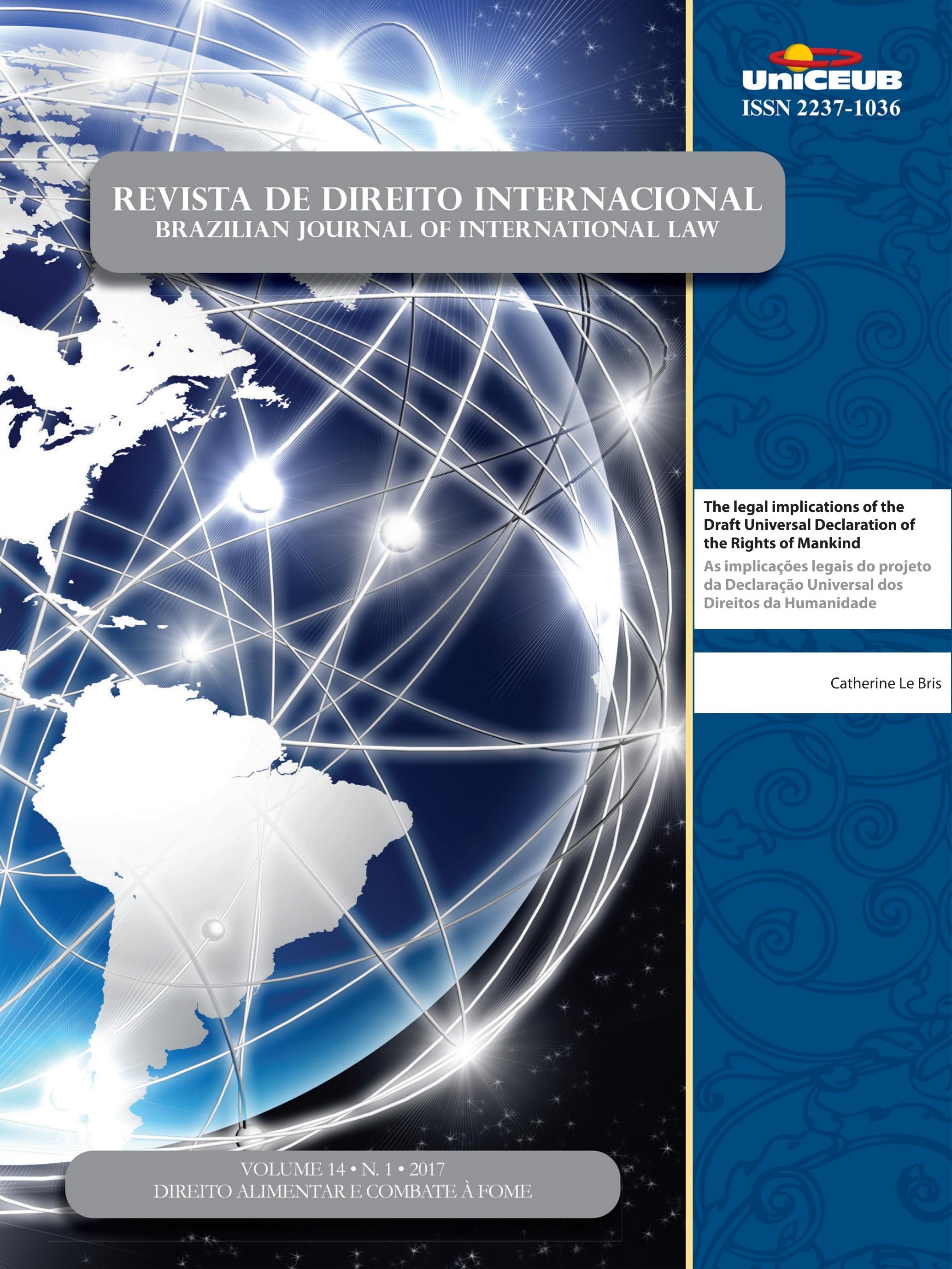




\section{Sumário}

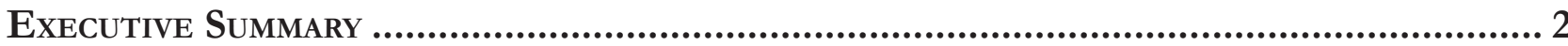

Daniel Balaban

Crônicas Sobre o Direito Alimentar e o Combate À Fome .............................................. 5

South-South Food and Nutrition Security promotion: the Brazilian experience

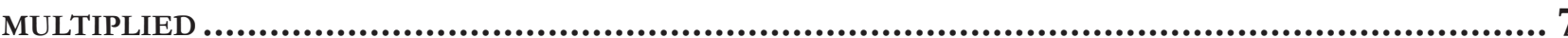

João Almino

Access to Food as a Human Right: Brazil, WFP and South-South Cooperation .......10 Carlos R. S. Milani

Dossiê temático: Direito Alimentar e Combate à Fome 13

WFP'S ROLE IN BUILDING SUSTAINABLE BRIDGES BETWEEN THE RIGHT TO ADEQUATE FOOD AND THE FREEDOM FROM HUNGER 15

Christiani Amaral Buani e Bruno Valim Magalhães

Direito humano À ALIMENTAÇÃo, (IN) SEgURANÇA ALIMENTAR E DESENVOLVIMENTO: OS DESAFios à REALIZAÇão PROGRESSIVA Na AMÉrica LATINa

Sinara Camera e Rubia Wegner

STATE'S INTERNATIONAL RESPONSIBILITY FOR THE HUMAN RIGHT TO FOOD: IMPLEMENTATION IN BRAZIL THROUGH AGROECOLOGY

Paula F. Strakos e Michelle B.B. Sanches

NegotiatiNg agRiCULtURE IN THE WORLD TRADE ORgANIZATION: FOOD SECURITY AS A NON-TRADE CONCERN.

Ana Luísa Soares Peres e Letícia de Souza Daibert

QUANDO HABITAR CORRESPONDE AO DIREITO HUMANO À ALIMENTAÇÃO

Fernanda Viegas Reichardt e Maria Elisa de Paula Eduardo Garavello 
The ROLE OF SUSTAINABLE LEARNING POLICIES ON THE FIGHT AGAINST

HUNGER IN ADULT EDUCATION.

Hiran Catuninho Azevedo

O DIREITO HUMANO E FUNDAMENTAL À ALIMENTAÇÃo ADEQUADA E À CONDIÇÃo

FEMININA NO PROGRAMA BOLSA FAMÍlIA: EMPODERAMENTO ÀS AVESSAS?

Rosalice Fidalgo Pinheiro e Laura Garbini Both

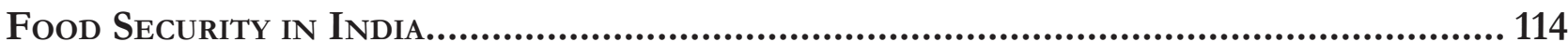

Ranjana Ferrão

SEguranÇA ALIMENTAR E A GOVERnANÇA ECONÔMICA GLOBAL

Danielle Mendes Thame Denny, Douglas de Castro, Alexandre Ricardo Machado, José Valverde Machado Filho e Gabrielle Fontes Witt

Outros Artigos.

The legal implications of the Draft Universal Declaration of the Rights of MANKIND

Catherine Le Bris

Litigating Indigenous Dispossession in THE Global Economy:

Law's Promises and Pitfalls................................................................................ 165

Charis Kamphuis

UNE DÉFINITION DU PRÉ-INVESTISSEMENT CONFORME À L'APPROCHE FRANÇAIS MAIS CONTRAIRE À L'APPROCHE AMÉRICAINE AU SEIN DES TRAITÉS BILATÉRAUX D'INVESTISSEMENTS IRANIENS

Peyman Dadras

CONFLITOS ENTRE REGULAÇÕES INTERNAS RELATIVAS À INTERNET E O DIREITO DO COMÉRCIO INTERNACIONAL: O PAPEL DA OMC PERANTE O SISTEMA DE COMPUTAÇÃO DA NUVEM ............238

Alice Rocha da Silva e Filipe Rocha Martins Soares

Prélèvement: origem, EVoluÇão e ocaso do Privilégio NAS SuCESSÕes INTERNACIONAIS NA FRANÇA

Fernando Pedro Meinero 
OS CONTRATOS INTERNACIONAIS DE FINANCIAMENTO E O CENTRO FINANCEIRO DE

Nova IorQue: CONSIDERAÇões SOBRE A AUTONOMIA DA VONTADE

Fernanda Torres Volpon

Mercosul e o Meio ambiente: ANÁlise da tUTELA REgional AMBIENTAL 284 Clarissa Ferreira Macedo D'Isep

Ainda (E uma Vez MAis) o SILÊNCIO QUe ENTOA O TRIUNFo De Lewis Carrol: A Regra N ${ }^{\circ} 42$ do Supremo Tribunal Federal

Thiago Aguiar Pádua e Bruno Amaral Machado

\section{A Natureza Jurídica do Sistema de Solução de Controvérsias da OMC} E DE SuAs Decisões: Solucionando um Imbróglio 316

Camila Capucio

Brics: Desafios do DESENVOLVIMENTO ECONÔMICO E SOCIOAMBIENTAI Magno Federici Gomes e Luís Eduardo Gomes Silva

REVER OU ROMPER COM VESTFÁLIA? POR UMA RELEITURA DA EFETIVA CONTRIBUIÇÃO DOS ACORDOS DE PAZ DE 1648 À CONSTRUÇÀO DO MODELO VESTFALIANO DE ESTADOS.

Luiz Magno Pinto Bastos Junior

Justiça de Transição EM SUA GÊNESE: A Alemanha Pós-NAZismo 378 Bruno Galindo

Quando JUlgar SE TORNa UM ESPETÁCulo: A INTERAÇão ENTRE o Supremo Tribunal Federal e a opinião pública, A PARTIR de REFlexões da LITERATURA ESTRANGEIRA

Patrícia Perrone Campos Mello

TolerânCia E refugio: um ENSAIO A PARTIR do ACORdo EU-TurQuia 425 Flávia Cristina Piovesan e Ana Carolina Lopes Olsen 


\title{
The legal implications of the Draft Universal Declaration of the Rights of Mankind*
}

\author{
As implicações legais do projeto da \\ Declaração Universal dos Direitos da \\ Humanidade
}

Catherine Le Bris**

\begin{abstract}
On 25th September 2015, the Draft Universal Declaration of the Rights of Mankind was presented to the French President François Hollande by the former Minister of Environment Mrs. Corinne Lepage and her team. What is the contribution of this Declaration? What is meant by Rights of Mankind? Are these new rights useful? This article aims to answer these questions by defining the rights of mankind, distinguishing them from human rights and putting them into perspective together with the duties towards mankind. This essay also deals with the institutional implications of this Declaration: Should mankind be represented by some sort of entity or body in order for it to exercise these rights? Who is entitled to speak on behalf of mankind?
\end{abstract}

Keywords: Universal Declaration of the Rights of Mankind. Draft. Normative and institutional implications.

\section{INTRODUCTION}

The rights of mankind ${ }^{1}$ or other human rights pertaining to the so-called "third generation rights" 2 do not have a good reputation. Skeptics consider them as being wishful thinking, ${ }^{3}$ vague ideals in respect of which attempts are made without success to make them resemble legal rights, while the bitterest skeptics only view them as a threat to freedoms. ${ }^{4}$

* Recebido em 14/02/2017

Aprovado em 21/02/2017

** Researcher at the National Centre for Scientific Research (Centre National de la Recherche Scientifique (CNRS), France) Institut des Sciences Juridique et Philosophique de la Sorbonne Université Paris 1 Panthéon-Sorbonne. Member of the Drafting Group for a Universal Declaration of the Rights of Mankind, drafed at the request of Mr. François Hollande, President of the French Republic under the lead of the Minister Mrs. Corinne Lepage. E-mail: catherinelebrisherve@gmail.com.
1 This article is a translation of an article drafted in French that was published in LE BRIS, Catherine. Le projet de déclaration universelle des droits de l'bumanité de 2015: implications et perspectives juridiques. 2016. Available in: <https://revdh.revues.org/2214\#text $>$. Access in: 4 out. 2015.

2 On a critical approach of the notion of third generation rights, see infra.

3 FRÉDÉRIC, Sudre. Droit international et européen des droits de l'homme. 9. ed. Paris: Presses universitaires de France, 2008, p. 110.

4 WECKEL, Philippe. Le rapport Lepage sur les droits de l'bumanité et le concept de l'bumanité indivisible. 2015. Available in: <www.sentinelle-droit-international.fr/?q=content/le-rapport-lepage-sur-les-droits-de-lhumanit $\% \mathrm{C} 3 \% \mathrm{~A} 9$-et-le-concept-de-lhumanit $\% \mathrm{C} 3 \% \mathrm{~A} 9$-indivisible $>$. Access in: 22 fev. 2015. "Face aux droits de la personne que vaudraient ces droits de l'espèce humaine, en tant qu'espèce vivante, attribués à une entité abstraite et globale, l'humanité? Au demeurant un catalogue des droits et devoirs suscite intuitivement l'hostilité des spécialistes des droits de l'homme". ("As far as human rights are concerned, the question arises as to what the role of these rights of mankind would be, if such rights were to be granted to an 
However, there are fewer authors who, emphasizing the potential of these rights, announce the entry in a new legal era: "With the help of mankind and that of the human aspect of international law, law should move forward and evolve without losing sight of its primary component, namely, the human society". ${ }^{5}$ Sometimes perceived as a promise and sometimes as a pipe dream, the rights of mankind give rise to conflicting lines of thought. While it is true that ideology is a system of images, ideas, philosophical or ethical principles, global stereotypes and organization of powers, ${ }^{6}$ the rights of mankind are the ideological rights par excellence: they bear a "World System" in themselves. ${ }^{7}$ Furthermore - and this also explains the aforementioned conflicting lines of thought - the rights of mankind serve as a catalyst of paradoxes. Echoing global concerns, these rights aim at solving what the philosopher Emmanuel Kant had described as "the greatest problem for the human race" and, thus, they are of an ambitious character. Yet, the realization of these rights requires, after all, the adoption of small-scale actions that, combined together, can ultimately reach their desired goal.

Historically, the ultimate goal of law has always been mankind. First, according to Stoic philosophy in Rome and subsequently, in the views of Vitoria, Suarez or Grotius, jus gentium would already be very close to a set of rights concerning mankind as a whole. ${ }^{9}$ However,

abstract and global entity (a living species) such as mankind? Moreover, an enumeration of rights and duties intuitively prompts a hostile reaction from human rights experts").

5 "L'humanité en tant qu'élément contribuant au développement progressif du droit international contemporain". SOMPONG, Sucharitkul. L'avenir du droit international dans un monde pluriculturel, colloque de l'Académie de droit international de La Haye. The Hague: Martinus Nijhoff Publishers, 1984. p. 427.

6 SERVIER, Jean. L'idéologie. Paris: PUF collection, 1982. p. 4

7 Expression forged by M. Griaule, quoted in SERVIER, Jean. L'idéologie. Paris: PUF collection, 1982.

8 See the "Fifth proposal" in KANT, Emmanuel. Idée d'une histoire universelle du point de vue cosmopolitique. Available in: <http:// classiques.uqac.ca/classiques/kant_emmanuel/idee_histoire_univ/ Idee_histoire_univ.pdf > . Access in: 21 mar. 2017. Pour la paix perpétuelle: projet philosophique, suivi d'un choix de textes sur la paix et la Guerre d'Erasme à Frend, translation, introduction, selection of texts and notes by Joël Lefebvre, Lyon, Presses universitaires de Lyon, collection "Le Livre de Poche",: "The greatest problem for the human race, to the solution of which Nature drives man, is the establishment of a universal civil society that administers law among all members of mankind". p. 121

9 The notion of jus gentium was used to name a wide variety of situations; in some of its widely varied meanings, it resembles a "general law of the universal society of mankind": see, in this regard, FORIERS, ano Apud TRUYOL Y SERRA, Antonio. Théorie this right of mankind sometimes forms an integral part of natural law and it is thus viewed not as a "small" set of rights (right of bumankind) but as a "great" set of norms ${ }^{10}$ concerning mankind (law of humankind). Only much later, when moral proved to be insufficient to protect human race from itself, mankind became the subject-matter of positive law. The "interests of humanity" and the "laws of humanity" were first used to humanize the armed conflicts. ${ }^{11}$ The prohibition of crimes against humanity itself was established in the aftermath of the Second World War in 1945. ${ }^{12}$ At that time, the main goal of the Charter of the United Nations was also to save "humankind" from the "untold sorrow" brought to it, ${ }^{13}$ this humankind being now considered as a "family" under the Universal Declaration of $\mathrm{Hu}$ man Rights. ${ }^{14}$ While Second World War contributed to an acceleration the collapse of the colonial empires, the legal aspect of mankind takes on a new dimension: in the context of the New International Economic Order, the States that emerged from decolonization call for solidarity and consider that mankind can serve as a basis for it. ${ }^{15}$ At the same time, technological discoveries rein-

du droit international public: cours general. Boston, 1981. p. 34. Available in: <http://referenceworks.brillonline.com/entries/the-hagueacademy-collected-courses/*-ej.9780792320500.009_443>. Access in: 21 mar. 2017. For further details on this matter, refer to our work: LE BRIS, Catherine. L'bumanité saisie par le droit international public. Paris: LGDJ, 2012. p. 6 et seq.

10 CARBONNIER, Jean. Flexible droit. 8. ed. Paris: LGDJ, 1995. p. 93 et seq.

11 See in particular the St. Petersburg Declaration (Declaration Renouncing the Use, in Time of War, of certain Explosive Projectiles, 11 December 1868) aimed at conciliating "the necessities of war with the laws of humanity as well as the preamble of the Convention (IV) respecting the Laws and Customs of War on Land and its annex (The Hague, 18 October 1907) where the Contracting Parties state that they are animated by the desire to serve "the interests of humanity" and to ensure that "in cases not included in the Regulations adopted [...], the inhabitants and the belligerents remain under the protection and the rule of the principles of the law of nations, as they result from the usages established among civilized peoples, from the laws of humanity, and the dictates of the public conscience".

12 See the Agreement for the Prosecution and Punishment of the Major War Criminals of the European Axis and the Charter of the International Military Tribunal.

13 Preamble of the Charter of the United Nations of 26 June 1945.

14 See the preamble of the Universal Declaration of Human Rights of 10 December 1948.

15 See in particular the recourse to the notion of "common heritage of mankind", which, on Professor Pierre-Marie Dupuy's opinion, makes reference to "normative strategies knowingly implemented by a group of States: those pertaining to the Third World, which come together in particular under the banner of the "Non-Aligned 
force the sense of belonging to the human race. The Earth is now perceived as Armstrong contemplated it from the Moon: as a unity. Astronauts are regarded as "envoys of mankind", ${ }^{16}$ outer space activities are deemed to be "province of all mankind" 17 and the moon and other celestial bodies are the "common heritage of mankind". ${ }^{18}$ The exploration of Antarctica and the discovery of the seabed areas give rise to the adoption of a similar course of action: these new spaces must also be managed in the interest of mankind. ${ }^{19}$ Everyone wants to benefit from these developments: in 1975, the Declaration on the Use of Scientific and Technological Progress in the Interests of Peace and for the Benefit of Mankind has been adopted..$^{20}$ In the course of time, as a result of the ecological disasters and the globalization of threats, solidarity becomes a necessity. Mankind is now deemed "a concrete whole". ${ }^{21}$ Furthermore, according to the terms of the Rio Declaration on Environment and Development, 1992, the "integral and interdependent nature of the Earth, our home" 22 has been recognized. Anyhow, when it comes to mankind, it is difficult to severe the object of the protection from the issue related to the subject of law, as both elements are closely linked. The Convention on the Law of the

Movement"'”: Dupuy Pierre-Marie, "Dialogue onirique avec Wolfgang Friedmann: sur les évolutions du droit international entre la fin des années soixante et la veille du XXIe siècle”. RUDA, Jose. Liber amicorum in memoriam of judge José Maria Ruda. The Hague: Kluwer law international, 2000. p.18.

16 Art. 5 of the Treaty on Principles Governing the Activities of States in the Exploration and Use of Outer Space.

17 See Art. 1 of the Treaty on Principles Governing the Activities of States in the Exploration and Use of Outer Space, including the Moon and Other Celestial Bodies, New York, 27 January 1967: "The exploration and use of outer space $[\ldots]$ shall be the province of all mankind."

18 See Art. 11(1) and Art. 1(1) of the Agreement Governing the Activities of States on the Moon and Other Celestial Bodies.

19 See in particular the preamble of the Antarctic Treaty of 1 December 1959 whereby reference is made to "the interest of all mankind", and Article 136 de la United Nations Convention on the Law of the Sea (Montego Bay, 10 December 1982, hereinafter the "United Nations Convention on the Law of the Sea") that characterizes the Area and its resources as "common heritage of mankind".

20 See resolution 3384 (XXX) of General Assembly of the United Nations of 10 November 197

21 MOREAU DEFARGES, Philippe. L'humanité, ultime "grande illusion" du XXème siècle? Politique étrangère, n. 3, 1999. p. 701.

22 UNITED NATIONS. Report of the United Nations Conference on Environment and Development. Available in: <http://www.globalforestcoalition.org/wp-content/uploads/2010/12/Rio-Declaration-onEnvironment-and-Development-principles.pdf $>$. Access in: 21 mar. 2017.
Sea confirms the foregoing: pursuant to Article 137, "all rights in the resources of the (seabed) area" ${ }^{\prime 23}$ are vested in mankind as a whole. Likewise, in the field of criminal law, according to the International Criminal Tribunal for the Former Yugoslavia, "[b]orders should not be considered [...] as a protection for those who trample underfoot the most elementary rights of humanity". ${ }^{24}$

The Draft Universal Declaration of the Rights of Mankind is an integral part of this movement towards the establishment of new rights for all human beings. It was at the Environmental Conference, organized by the French government in October 2014, that the suggestion was made when the President of the French Republic, Mr. François Hollande expressed his will that "after the rights of persons [...] it was time to lay down basis for the rights of mankind". ${ }^{25}$ Subsequently, Mrs. Corinne Lepage, former Minister for the Environment in France, ${ }^{26}$ who was responsible for allowing such a proposal to become a reality and her drafting team submitted a report on this issue to the President of the French Republic on 25 September 2015. ${ }^{27}$ This report proposes a draft Declaration recognizing six rights of mankind (the right to the environment, the right to development, the right to the common and global heritage, the right to common goods, the right to peace and the right to have freedom of choice to determine

23 Art. 137(2) of the United Nations Convention on the Law of the Sea.

24 ICTY, Prosecutor c. Tadic, case n IT-94-1, 2 October 1995, Decision, $\int 58$.

25 See the mission statement by the President of the French Republic Mr. François Hollande addressed to Mrs. Corinne Lepage dated 4 June 2015, which is contained in LEPAGE CORINNE ET EQUIPE DE RÉDACTION. Déclaration universelle des droits de l'bumanité, rapport à l'attention de Monsieur le Président de la République. 2015. p. 7 et seq. Available in: <http://www.ladocumentationfrancaise.fr/var/storage/rapports-publics/154000687.pdf>. Access in: 23 fev. 2016.

26 From 1995 to 1997.

27 LEPAGE CORINNE ET EQUIPE DE RÉDACTION. Déclaration universelle des droits de l'bumanité, rapport à l'attention de Monsieur le Président de la République. 2015. Available in: <http://www.ladocumentationfrancaise.fr/var/storage/rapports-publics/154000687. pdf $>$. Access in: 23 fev. 2016. Regarding this Draft Declaration, see in particular: DELZANGLES, Hubert. Remise de la Déclaration des droits de l'humanité: quelle place pour la protection de l'environnement?. Actu Environnement, 2015. Available in: <https:// www.actu-environnement.com/ae/news/hubert-delzangles-declaration-droits-humanite-place-protection-environnement-25834. php4> Access in: 21 mar. 2017.; DROITS de l'humanité. La Semaine Juridique - Édition Générale, n. 50, 2015. p. 2268; OTTOU, Alix; DORIS, Marion. Vers une déclaration universelle des droits de l'humanité?. Revue des droits de l'homme. 2016. Available in: <https:// revdh.revues.org/1769>. Access in: 21 mar. 2017. 
its own fate) and six duties towards mankind (the duty to ensure respect for the rights of mankind, the duty to preserve environmental heritage and resources, the duty to preserve climate equilibrium, the duty to guide scientific and technical progress, the duty to promote sustainable human development, the duty to ensure the effectiveness of the principle, rights and duties of the Declaration); these rights and duties are coupled with four guiding principles ${ }^{28}$ (the principle of responsibility, equity and solidarity, the principle of the dignity of mankind, the principle of the continuity of the existence of humanity, the principle of non-discrimination against future generations) that serve as their basis and guide their implementation. This Draft Declaration was formally presented at the Climate Conference (COP21) in Paris in 2015. ${ }^{29}$ At the time of the adoption of the Paris Agreement on 12 December 2015, President François Hollande emphasized that "to human rights we have just added the rights of mankind." ${ }^{30}$ The Agreement itself describes climate change, by linking, for the first time, such characterization to human rights, as "a common concern of humankind" ${ }^{31}$ In the long term, the Draft Declaration could be placed on the agenda of the UN General Assembly for its consideration and adoption. ${ }^{32}$ The Declaration is intended to become a soft law instrument. The use of soft law is particularly appropriate in this scenario, as the rights of mankind may disrupt the mechanisms of classical international law.

28 See the Draft Universal Declaration of Rights of Mankind reproduced in the Annex to this document. For a commentary on every article of this Declaration. LEPAGE CORINNE ET EQUIPE DE RÉDACTION. Déclaration universelle des droits de l'bumanité, rapport à l'attention de Monsieur le Président de la République. 2015. Available in: <http://www.ladocumentationfrancaise.fr/var/storage/rapportspublics/154000687.pdf>. Access in: 23 fev. 2016.

29 An official side event concerning the draft Declaration was organized at the French Pavilion during the COP21.

30 L'ELYSÉE, Palais de. Tweet of 12 December 2015: Available in: $<$ https://twitter.com/elysee/status/675771304381964288>. Access in: 23 fev. 2016.

31 The Preamble of this Agreements establishes that: "Acknowledging that climate change is a common concern of humankind, Parties should, when taking action to address climate change, respect, promote and consider their respective obligations on human rights, the right to health, the rights of indigenous peoples, local communities, migrants, children, persons with disabilities and people in vulnerable situations and the right to development, as well as gender equality, empowerment of women and intergenerational equity". LE BRIS, Catherine. Les changements climatiques, une préoccupation pour l'bumanité. Available in: <https://theconversation.com/ les-changements-climatiques-une-preoccupation-pour-lhumanite-52708>. Access in:23 fev. 2016.

32 The Draft Declaration was forwarded by President François Hollande to the United Nations Secretary-General on 28/04/2016.
Indeed, in the Westphalian order, the normative space is identified with the State, the temporal power rest with sovereignties and hence the legal landscape appears relatively peaceful "under the reassuring sign of unity and stability". ${ }^{33}$ On the contrary, humanity reflects a "global notion in space and in time" 34 : it displaces the frozen time of the State in favor of the changing time of human needs and pushes back the boundaries in a quest of universality. Against this background, the rights of mankind cannot be designed to take precedence abruptly over sovereignty. However, between soft law and hard law, there are bridges: through practice and belief in these practices, the norms set forth in this Declaration could eventually become international customary law. Some of them could also eventually be included in one or more conventions. This Declaration could thus be only the first step in a relatively long process.

For this process to begin, however, several issues must first be examined: What is the meaning of this entity, mankind, in whose favor rights will be granted? How the rights of mankind can be defined? Are these rights useful? And what is the impact of the duties towards mankind in this context? All these questions are mingled with fears: concerns are raised about how these new rights will interplay with human rights ${ }^{35}$ and one can wonder who will be able to exercise these rights granted to this entity called mankind whose notion seems elusive. Therefore, the fact of underscoring the normative (I) and institutional (II) implications of this Draft Declaration will allow for its potential to be identified and, beyond the legal utopia, fully realized.

\section{RIGHTS OF MANKIND AND DUTIES TOWARDS MANKIND: NORMATIVE IMPLICATIONS OF THE Draft Declaration}

The vision of mankind as holder of rights is "as revolutionary on a global scale as the integration into the French constitutional law of the eighteenth century of the concept of Nation as holder of sovereignty re-

33 DELMAS-MARTY, Mireille. Trois défis pour un droit mondial. Paris: Éditions du Seuil, 1998. p. 92.

34 DUPUY, René-Jean. La communauté internationale entre le mythe et l'bistoire. Paris: Economica, 1986. p.169.

35 See WECKEL, Philippe. Título. Local: editora, ano. this Declaration would "intuitively prompt a hostile reaction from human rights experts". 
placing the monarch". ${ }^{36}$ This "vision" has been expressed by means of variety of terms: while some authors have sought to stress the biological unity of mankind by making reference to the "rights of the human species", 37 others have emphasized the social implications of these rights ("rights of human solidarity"), ${ }^{38}$ their scope of application ("global rights") 39 or their philosophical impact ("rights of the "human family"). ${ }^{40}$ The notion of "rights of mankind" is the most stable and widespread: it has been used since the end of the nineteenth century in official texts, ${ }^{41}$ and has been included in a number of books, ${ }^{42}$ articles $^{43}$ or academic works. ${ }^{44}$ This notion

36 PANCRACIO, ano Apud TERRÉ, François. L'humanité, un patrimoine sans personne. In: ARDANT, Philippe. Droit et politique à la croisée des cultures. Paris: LGDJ, 1999. p. 346.

37 HUBER, Gérard. Le clonage humain est-il un crime contre l'humanité. Droit et économie, n. 85, 1999. p.23.

38 NICIU, Martian I. Le patrimoine commun de l'humanité en droit international maritime et en droit spatial Annuaire de droit maritime et océanique, 1995. p. 16.

39 WEISS, Edith Brown. Justice pour les générations futures: droit international: patrimoine commun et équité intergénérations. Paris: Éditions Sang de la terre, Unesco, 1994. p. 89 et seq.

40 DELMAS-MARTY, Mireille. Europe du marché, Europe des droits de l'homme. In: GROS, François; HUBERT, Gérard. Vers un anti destin? Patrimoine génétique et droits de l'bumanité. Paris: Odile Jacob, 1992. p. 415.

41 In 1919, during the Paris Peace Conference, the British delegation stated that the offenders have trampled underfoot international law and the sacred rights of mankind [Translation]. GRAVEN, Jean. Les crimes contre l'humanité, RCADI, v. 76, 1950. p. 447.

42 See in particular the works by French Professor René-Jean Dupuy concerning the concept of mankind and, especially. DUPUY, René-Jean. La communauté internationale entre le mythe et l'histoire. Paris: Economica, 1986. p. 152 (whereby reference is made to "general rights of mankind") and DUPUY, René-Jean. L'bumanité dans l'imaginaire des nations. Paris: Julliard, 1991. p. 200. ("the recognition of mankind and their rights"). See also BEDJAOUI, Mohamed. Pour un nouvel ordre économique international. Paris: UNESCO, 1978. p. 230. "Droits de l'humanité tout entire". "The rights of mankind as a whole".

43 CARRILLO-SALCEDO, Juan Antonio. Le concept de patrimoine commun de l'humanité. In: HOMMAGE à René-Jean Dupuy, Ouvertures en droit international. Paris: Pedone, 2000. p. 61; CASSAN, Hervé. Humanité et développement: quelques remarques prospectives. In: FLORY, Maurice; HENRY, Jean-Robert. MAHIOU, Ahmed. La formation des norms en droit international du développement. Paris: CNRS, 1984. p. 200-201; DUPUY, Pierre-Marie. Humanité, communauté et efficacité du droit. In: DUPUY, René-Jean. Humanité et droit international: mélanges. Paris: Pedone, 1991. p. 137; KAMTO, Maurice. La volonté de l'État en droit international. RCADI, v. 310, 2004. p. 327; KOUASSI Kanga. Le concept de patrimoine commun de l'humanité et l'évolution du droit international public. Revue juridique et politique: indépendance et cooperation, 1995. p. 951. (la reconnaissance de droits à l'humanité); TRINDADE, Antônio Augusto Cançado. International law for humankind: towards a new jus gentium (I) et (II). General course of public international law, RCADI, v. 316, 2005. p. 328.

44 DATONOU, Dieudonné. Du concept de patrimoine commun de has also been used in international instruments ${ }^{45}$ and in court $^{46}$. Efforts to define these rights of mankind have proved to be necessary, although sometimes the resulting definitions have created some degree of confusion with notion of human rights $(A)$. It is by drawing a clear distinction between the two notions that the scope of the rights of mankind and their corollary - the duties towards mankind - can be fully assessed (B).

\subsection{Rights of mankind and human rights: between autonomy and interdependence}

Mankind, in the definition given by the French philosopher Auguste Comte, is an "immense and eternal social unity", ${ }^{47}$ bound by solidarity. It is composed of both the living and "the unborn". ${ }^{48}$ Moreover, mankind covers all individuals and groups, in particular peoples, non-governmental organizations and States and also embraces all generations. This definition is reproduced in the draft Declaration: " $[\mathrm{M}]$ ankind, which includes all human individuals and organizations, covering past, present and future generations". While according to the analyses carried out by the French historian Ernest Renan the nation relies heavily on the past legacy, the legal aspect of mankind is of a prospective nature rather than a retrospective one: it "embodies the future rather than the present day. It would represent eternity if history were not to come to an end". ${ }^{49}$

Mankind, in its capacity of holder of rights, is indivisible. It must be regarded as an inextricable and inseparable combination of individuals, groups and

l'bumanité aux droits de l'bumanité, étude historico-juridique du concept de patrimoine commun de l'bumanité em droit international, excerpta ex dissertatione ad doctoratum in utroqueiure. Roma: Pontificia Università Laternense, 1995. $145 \mathrm{p}$.

45 Regarding binding instruments, see Art. 137(2) of the United Nations Convention on the Law of the Sea: "All rights in the resources of the [...] Area are vested in mankind as a whole" (Emphasis is ours).

46 See ICTY, Prosecutor v. Tadic, 2 October 1995, cited above, $\mathbb{S}$ 58 ("the most elementary rights of humanity"). In the Barbie case, before the French courts, the Attorney-General Dontewille has made reference several times to the "rights of mankind": see Ruzié David, «Commentaire sous Cass. Crim, 6 octobre 1983, Barbie (Report by M. Le Conseiller Le Guhenec ; Conclusions de M. L’Avocat Général Dontenwille et arrêt) », La Semaine Juridique (JCP), 1983, II, 20107.

47 GRAVEN, Jean; CASSIN, René. Le difficile progrès du règne de la justice et de la paix internationales par le droit. des origines à la Société des Nations. Paris: Pedone, 1970. p. 277.

48 KOFMAN, Sarah. Penser l'humanité. Actes: droit et humanité: Les cahiers d'action juridique, n. 67-68, Sep. 1989, p. 9.

49 DUPUY, René-Jean. Réflexions sur le patrimoine commun de l'humanité. Droits, n.1, 1985. p. 69. 
generations. ${ }^{50}$ In practice, each generation does not go on the stage of history "as just one man" nor does it leave it "as a group", ${ }^{11}$ as generations intermingle. This reality has not only philosophical implications, but also legal and litigious consequences: if mankind is a unity, this means that the so-called rights of "future generations" are only one aspect of the rights of mankind and therefore, these rights are not to be understood as an autonomous notion. Against the background, "future" generations cannot, when they become "present generations" turn against "past" generations.

In the Draft Universal Declaration of the Rights of Mankind of 2015, mankind and nature are deemed to be interdependent. In other words, the Draft Declaration excludes those conceptions that separate mankind from nature: it refuses to view the environment as an object that is at the service of mankind. However, it does not characterize nature as a legal person. It establishes a third way, which is that of nature as a project ("nature-projet") ${ }^{52}$ : such a perspective reflects an eco-anthropocentric approach, according to which mankind and nature are inextricably linked. The reference to "living species" in the Declaration - which had been suggested by the American essayist Jérémy Rifkin, a member of the working group of Mrs. Corinne Lepage - aims at reflecting this interdependence between the human species and the other species.

The rights of mankind, which have been conceived along the lines of their holder, feature two major characteristics: they are of a collective and of an intergenerational nature.

The notion of "collective right" is ambiguous. It can mean that the right concerned can only be collectively exercised, particularly since the right itself - its enjoyment - is of an individual nature (along the lines of the right to strike, for instance). However, it can also mean that the holder of the right is a group and it is in this sense that it must be construed here. The rights of mankind, which are granted in favor of the human community,

50 CHEMILLIER-GENDREAU, Monique. Humanité et souveraineté, essai sur la fonction du droit international. Paris: La Découverte, 1995. p. 358.

51 OST, François. Elargir la communauté politique : par les droits ou par les responsabilités? Réflexions sur les enjeux éthiques de la crise écologique. In: BERNS, Thomas. Le droit saisi par le collectif. Bruxelles: Bruylant, 2004. p. 258.

52 OST, François. La nature hors la loi: l'écologie à l'épreuve du droit: l'écologie à l'épreuve du droit. Paris: La Découverte, 2003. p. 237 et seq. cannot be subsumed in an aggregation of individual rights; they concern all human beings and "do not belong to any of them in particular". ${ }^{33}$ The legally protected interest related to the rights of mankind is of a diffused character - as these rights concern an indefinite number of individuals or groups. ${ }^{54}$ Such interest is also indivisible, that is, it cannot be split up. ${ }^{55}$ This is the reason why the rights of mankind have sometimes been called "rights of solidarity". This solidarity, inherent to these rights, manifests itself in space (covering different groups, cultures and peoples) and in time (through succeeding generations). Indeed, the rights of mankind are also intergenerational: the principle of transmission that underpins them is one of their specific features. Under the terms of the draft Declaration, the "continuity of mankind rests on this intergenerational link". ${ }^{56}$

The rights of mankind, by virtue of their features, are distinguished from human rights. While the latter are aimed at protecting individual freedoms (freedom of expression, freedom of movement, etc.) and making these freedoms effective (economic and social rights, as well as civil and political rights such as the right not to be subjected to degrading treatment or the right to participating in public affairs), ${ }^{57}$ the rights of mankind aim to safeguard the essential interests of the human race

53 DUPUY, René-Jean. Humanité et droit international: mélanges. Paris: Pedone, 1991. p. 137.

54 DUfFRENE, Marie Pierre Camproux. La représentation de l'intérêt collectif environnemental devant le juge civil : après l'affaire Erika et avant l'introduction dans le Code civil du dommage causé à l'environnement. Vertigo, 2015. Available in: < https://vertigo.revues.org/16320>. Access in: 23 fev. 2016.

55 DUFFRENE, Marie Pierre Camproux. La représentation de l'intérêt collectif environnemental devant le juge civil : après l'affaire Erika et avant l'introduction dans le Code civil du dommage causé à l'environnement. Vertigo, 2015. Available in: < https://vertigo.revues.org/16320>. Access in: 23 fev. 2016.

56 See the Preamble of the Draft Universal Declaration of the Rights of Mankind, 2015. FRANCE. Présidence de la République. Déclaration universelle des droits de l'bumanité, rapport à l'attention de Monsieur le Président de la République. 2015. Available in: <http://www. ladocumentationfrancaise.fr/rapports-publics/154000687/index. shtml>. Access in: 23 mar. 2017.

57 For a more detailed analysis of this issue, see LE BRIS, Catherine. L'bumanité saisie par le droit international public. Paris: LGDJ, 2012. p. 81 et seq. Regarding the interplay between "human rights" and "freedoms". CHAMPEIL-DESPLATS, Véronique. Des "libertés publiques" aux "droits fondamentaux" : effets et enjeux d'un changement de denomination. Jus Politicum, n. 5, 2010. p. 3. Available in: <http://juspoliticum.com/uploads/pdf/JP5_Champeil_corr01. pdf>. Access in: 23 fev. 2016. 
(right to development, ${ }^{58}$ right to common heritage, ${ }^{59}$, right to peace, ${ }^{60}$ right to a sustainable environment, ${ }^{61}$ etc.). Both rights of mankind and human rights fall under different temporal scopes: human rights are exercised in the present time, while the rights of mankind, which also concern "future generations", are projected into the future as well. These two types of rights are also differentiated by the subject matter concerned: while the holders of human rights are individuals, ${ }^{62}$ the rights of mankind are conferred upon the human community as an autonomous entity.

This does not mean that mankind does not play a role in the human rights sphere: human nature, and therefore mankind, ${ }^{63}$ constitutes the criterion upon which human rights are recognized. ${ }^{64}$ These rights must be res-

58 See Art. 6 of the Draft Universal Declaration of the Rights of Mankind contained in the Annex.

59 See Arts. 7 and 8 of the Draft Universal Declaration of the Rights of Mankind contained in the Annex.

60 See Art. 9 of the Draft Universal Declaration of the Rights of Mankind contained in the Annex.

61 See Art. 6 of the Draft Universal Declaration of the Rights of Mankind contained in the Annex.

62 It is true that legal persons (e.g. non-governmental organizations within the framework of the European Convention on Human Rights) may also invoke human rights for their own benefit; this is a legal fiction to ensure the efficiency and effectiveness of those freedoms that are collectively exercised but the enjoyment of which is of an individual nature. The individual is not completely obliterated behind the legal person concerned in the process of recognition of fundamental rights: "first of all, at issue are here the persons who have established and are members (associates, co-owners, supporters) of the entity having been granted legal personality"; these rights "are not in principle attributes associated with the quality of the subject of law but with the rights recognized in favor of all human beings. While our legal system confers such rights upon legal entities, it does not do so only because they have been endowed with legal personality but because they are organizations pursuing lawful purposes, or furthermore, because they reflect the exercise by their founders or members of a freedom, namely, the freedom of association, of course, but also the freedom to undertake economic activities, religious freedom, etc." (BOULOIS, Xavier Dupré de. Les droits fondamentaux des personnes morales. Revue des droits et libertés fondamentaux, n. 15, 2011. Available in: <http://www.revuedlf.com/ droit-fondamentaux/les-droits-fondamentaux-des-personnes-morales- $\%$ E2\%80\%93-1ere-partie/>. Access in: 03 maio 2016.)

63 On the polysemy and the different meanings of the term "makind"("humanité"), LE BRIS, Catherine. L'bumanité saisie par le droit international public. Paris: LGDJ, 2012. p. 30 et seq.

64 Admittedly, legal persons, that is, those "cold monsters devoid of humanity", can also invoke human rights for their own benefit, but as stated above (note no. 57); the use of this legal fiction aims to guarantee the effectiveness and effectiveness of those freedoms, the exercise of which is of a collective nature, but their enjoyment is of an individual character: BOULOIS, Xavier Dupré de. Les droits fondamentaux des personnes morales. Revue des droits et libertés fondamentaux, n. 15, 2011. Available in: <http://www.revuedlf.com/ pected vis-à-vis all persons "by reason of their human structure". ${ }^{65}$ The inherent humanity of every person is a source of rights. Therefore, the rights of mankind and human rights are built on the same belief in the universality of human nature. ${ }^{66}$ This explains why both types of rights are indivisible and objective in character, that is, they fall outside the principle of reciprocity, "the golden rule for relations between States". ${ }^{67}$

However, the difference between these two types of rights lies in their very nature and not only in their importance. In the case of the rights of mankind, humanity itself is no longer a criterion for granting rights; mankind becomes the holder of those rights. From this perspective, these rights represent "a qualitative leap forwards that makes them fall outside the category of human rights". ${ }^{68}$ This difference has not always been properly understood. The cause of this confusion lies in the so-called "third-generation" human rights theory. According to this approach, it would be possible to identify three "generations" of human rights: civil-political freedoms ("libertés-aptitudes"), socio-economic rights ("droits-créances) and solidarity rights ("droits de solidarities"). ${ }^{69}$ This approach has - with good reasonbeen criticized by scholarly literature, and although it is not necessary to revisit all these criticisms, ${ }^{70}$ it should be noted that not only might it suggest that certain human rights would pertain to different "generations", and would therefore no longer be relevant today, but, moreover, such an approach dilutes the very concept of human rights: according to this theory the holder of these rights and their subject matter can no longer be clearly identified. In this context, the concept of "third-

droit-fondamentaux/les-droits-fondamentaux-des-personnes-morales-\%E2\%80\%93-1ere-partie/>. Access in: 03 maio 2016.

65 SUSTERHENN, Adolf. L'idée des droits de l'homme et sa mise en œuvre. In: MÉLANGES offerts à Henri Rolin: problèmes du droit des gens. Paris: Pedone, 1964. p. 398.

66 DUPUY, Pierre-Marie. Humanité, communauté et efficacité du droit. In: DUPUY, René-Jean. Humanité et droit international: mélanges. Paris: Pedone, 1991. p. 137.

67 DUPUY, René-Jean. L'bumanité dans l'imaginaire des nations. Paris: Julliard, 1991. p. 202.

68 DATONOU, Dieudonné. Du concept de patrimoine commun de l'bumanité aux droits de l'bumanité, étude historico-juridique du concept de patrimoine commun de l'bumanité em droit international, excerpta ex dissertatione ad doctoratum in utroqueiure. Roma: Pontificia Università Laternense, 1995. p. 125.

69 COLARD, Daniel. Le droit à la paix comme droit de l'homme. Les Cabiers du droit public, 1988. p. 33.

70 For a critical approach on this theory, LE BRIS, Catherine. L'bumanité saisie par le droit international public. Paris: LGDJ, 2012. p. 83 et seq. 
-generation rights" is likely to undermine human rights as a whole.

While human rights and the rights of mankind must be distinguished, they must not, however, be considered as opposing concepts. These two types of rights are "indivisible" as recalled in the Draft Declaration. ${ }^{71}$ The recognition of the rights of mankind is a guarantee of the effectiveness of individual rights: once the concept of mankind is accepted, humanity "must itself enjoy their rights, otherwise individuals would lose theirs". ${ }^{72}$ In this regard, the United Nations Human Rights Committee has stated that "[e]very effort they [States] make to avert the danger of war [...] constitute[s] the most important condition and guarantee for the safeguarding of the right to life", thus recalling the interdependence between the right of mankind to peace and the right of man to life. ${ }^{73}$ The links that are woven between human rights and rights of mankind are not limited to civil and political rights but also involve economic and social rights. A close relationship exists, in particular, between the individual right to health and the right of mankind to the environment. ${ }^{74}$ For example, in 2013, the Athabaskan peoples filed a petition with the Inter-American Commission on Human Rights against Canada whereby they basically allege that the inaction of that State against black carbon emissions, which contribute to climate change, violates in particular their right to life and health. ${ }^{75}$ It is likely that, as in the case of the petition filed against the United States on behalf of the Inuit

71 See Article 11 of the Draft Universal Declaration reproduced in the Annex.

72 DUPUY, René-Jean. La clôture du système international: la cité terrestre. Paris: Presses Universitaires de France, 1989. p. 156.

73 Human Rights Committee (HRC), General Comment 6, Article 6 (Sixteenth Session) on the International Covenant on Civil and Political Rights (right to life), 30 April 1982, \2, (Doc. UN HRI GEN $\backslash 1 \backslash$ Rev.1).

74 See the African Commission on Human and Peoples' Rights (ACHPR), 27 October, 2001, Social and Economic Rights Action Center (SERAC) and Center for Economic and Social Rights (CESR) c. Nigéria, aff. 155/ 96. On this subject, see also DUPUY, Pierre-Marie. Le droit à la santé et la protection de l'environnement. In: DUPUY, René-Jean. Le droit à la santé en tant que droit de l'homme. La Haye: Sijthoff\&Noordhoff, ano. p. 340 et seq. (in particular, p. 405).

75 ATHABASKAN COUNCIL. Petition to the Inter-American Commission on human rights seeking relief from violations of the rights of arctic Athabaskan peoples resulting from rapid arctic warming and melting caused by emissions of black carbon by Canada. 2013. Available in: <http:// earthjustice.org/sites/default/files/AAC_PETITION_13-04-23a. pdf $>$. Access in: 23 fev. 2016. Regarding this case, see CANALFORGUES, Eric; PERUSO, Camila. La lutte contre le changement climatique en tant qu'objet juridique identifié. LexisNexis, n. 8-9, comment 72, August 2015. p. 52. peoples in $2005,{ }^{76}$ the Commission concludes that no link between the greenhouse gas emissions and the alleged violations of human rights could be proved. ${ }^{77}$ This is precisely one of the advantages of recognizing the rights of mankind in the international legal order: this would allow for the circumvention of the issue concerning the proof of an individual and present (or imminent) violation, as that issue constitutes a barrier to the admissibility of this type of cases.

The fact remains that recognizing the interdependence between human rights and the rights of mankind does not solve everything: it is an undeniable fact that "the greater the number of rights, the greater the chances that disputes arise", and that those rights conflict with each other. ${ }^{78}$ The problem is not new: in former times, René Cassin ${ }^{79}$ explained that he had already criticized the 1948 Universal Declaration of Human Rights for establishing "an impossible conciliation" between classical freedoms and economic, social and cultural rights, which are more innovative. ${ }^{80}$ At present, there may be some concerns about the transcendent character of the rights of mankind and the possible risks of taking measures that endanger freedoms. ${ }^{81}$ It would be a mistake to consider that collective issues take precedence over the individual ones, or vice versa. An absolutist and overriding approach to the rights of mankind must be rejected. As a matter of fact, the legal aspect of mankind is not only transcendental, it is also

76 ATHABASKAN COUNCIL. Petition to the Inter-American Commission on buman rights seeking relief from violations of the rights of arctic Athabaskan peoples resulting from rapid arctic warming and melting caused by emissions of black carbon by Canada. 2013. Available in: <http://earthjustice.org/sites/default/files/AAC_PETITION_13-04-23a.pdf $>$. Access in: 23 fev. 2016.

77 WOLD Chris; HUNTER, David; POWERS, Mélissa. Climate change and the law. 2. Ed. New York: LexisNexis, 2013. p. 591 et seq.: the Inter-American Commission dismissed the petition on the grounds that it did not allow for a determination to be made as to whether the alleged facts implied a violation of the rights protected by the Inter-American Convention on Human Rights; (see p. 595). 78 WEISS, Edith Brown. Justice pour les générations futures: droit international: patrimoine commun et équité intergénérations. Paris: Éditions Sang de la terre, Unesco, 1994. p. 95.

79 René Cassin is a French Lawyer and Diplomat. He is one of the drafters of the Universal Declaration of Human Rights 1948.

80 CASSIN, René. La Déclaration universelle et la mise en œuvre des droits de l'homme. RCADI, v. 79, 1951. p. 285.

81 WECKEL, Philippe. Le rapport Lepage sur les droits de l'bumanité et le concept de l'bumanité indivisible. 2015. Available in: <www.sentinelledroit-international.fr/?q=content/le-rapport-lepage-sur-les-droitsde-lhumanit $\%$ C3\%A9-et-le-concept-de-lhumanit $\%$ C3\%A9-indivisible>. Access in: 22 fev. 2015. 
immanent: ${ }^{82}$ mankind is not more important than its members, "it is they who are its essence". ${ }^{83}$ Furthermore, "each right can only be the beginning of a right" and be capable of deferring to another right in the event of a conflict among them. ${ }^{84}$ On a practical level, it is important to identify the criteria or methods allowing for the resolution of assumptions of conflicts between the rights of mankind and human rights. A preliminary step aims at finding the causes of the conflicts, the conditions surrounding their emergence, so as to prevent them. The objective would thus be to reduce those contradictory requirements so as to avoid giving up one of the categories of rights concerned. Should the conflict be inevitable, it is necessary to seek to reconcile those competing rights without establishing a hierarchy among them. To this end, it is possible to weigh up the two competing rights; well-proven techniques based in particular upon the principles of necessity and proportionality can prove to be useful in this context. In addition, certain legal criteria such as the non-derogable nature of the right concerned should also be taken into account. In any event, it is important to avoid systematically giving priority to a right over another..$^{85}$

\subsection{Duties towards mankind and rights of mankind: between complementarity and added value}

The recognition of the rights of mankind beyond its symbolic character has both theoretical and practical interest.

From a theoretical perspective, the Draft Declaration introduces a new legal category, ${ }^{86}$ the so-called ri-

82 LE BRIS, Catherine. L'bumanité saisie par le droit international public. Paris: LGDJ, 2012. p. 41.

83 DUPUY, René-Jean. L'humanité dans l'imaginaire des nations. Paris: Julliard, 1991. p. 41.

84 Edith Brown-Weiss, ibid., p. 94. Consequently, even the right not to be subjected to inhuman or degrading treatment may defer to the freedom of individuals over their own bodies: see European Court of Human Rights, judgment delivered on 17 February 2005, K.A and A.D. v. Belgium, Applications nos. 42758/98 and 45558/99 (concerning sadomasochism).

85 On the issue related to conflicting fundamental rights, see the informal noted by Françoise Tulkens concerning «Les conflits de droits fondamentaux» of 14 April 2006. Document available online at: [http://www.ies.be/files/Fr.Tulkens.Notes_de_support_au_ cours_du_16_f\%C3\%A9vrier_2007.pdf] (last 23/02/2016).

86 It is possible to believe that a legal category exists "given that the legislation incorporates it into its own lexicon and legal consequences are attached to it": see, on this issue, Lochak Danièle, ghts of mankind. This category allows for norms, things, facts or acts focused on the interest of mankind to be dealt with as a whole and be governed by a common legal regime. Failing this, the recognition of the interests of mankind would only consist of "a jumble of heterogeneous rules", a "simple juxtaposition of diverging rules" that are impossible to be applied and that inevitably involve contradictions among them. ${ }^{87}$ As a new category, the rights of mankind emerge as a strong normative basis to ensure the connection between legal notions such as "(common/global) heritage of mankind", "common concern of mankind", "human security", "human development", "human interest" or "crime against humanity". In environmental matters, in particular the recognition of this category makes it possible to adapt the legislation to empirical developments when dealing with what is often referred to as "ecological interdependence". To take just one example, climate change, which from a legal perspective, is "a common concern of humankind" 88 having an impact on glaciers in Antarctica - a region whose environmental protection is "in the interest of mankind as a whole" ${ }^{89}$-, is also closely linked to the oceans whose seabed is the common heritage of mankind. ${ }^{90}$ Thus, climate change can deteriorate the world heritage of mankind such as the Great Barrier Reef ${ }^{91}$ and can ultimately pose a threat to human security. ${ }^{92}$ Thus, by recognizing the category of rights of mankind, the international legal order is in tune with the circumstances that it governs.

From a practical point of view, the recognition of the rights of mankind contributes to increasing res-

«La race: une catégorie juridique?», in Actes du colloque Sans distinction de... race, 27 -28 March 1992, published in Mots no. 33. Available online:[http://www.anti-rev.org/textes/Lochak92a/] (Last visited 24/02/2016).

87 Bergel Jean-Louis, Théorie générale du droit, Paris, Dalloz, 2012, p. 225 et s.

88 Preamble of the United Nations Framework Convention on Climate Change of 9 May 1992 and Preamble of the Paris Agreement of 12 December 2015.

89 Protocol Environmental Protection to the Antarctic Treaty, Madrid, 4 October 1991.

90 See Article 136 of the United Nations Convention on the Law of the Sea.

91 See the Convention for the Protection of the World Cultural and Natural Heritage, Paris, 16 November 1972. The World Cultural List is available on the Web site of Unesco at: [http://whc.unesco. $\mathrm{org} /$ en/list/154/] (Last visited 24/02/2016).

92 Regarding the notion of human security, see in particular, United Nations Development Programme, Human Development Report 1994 : New Dimensions of Human Security, Paris, Economica, 1994, p. 240. 
ponsibilities insofar as these rights are conceptualized in terms of creditors and debtors. Indeed, where a subjective right is created, its holder is granted the power to make demands and the norm concerned is thus assorted with a number of mechanisms to which recourse will be had upon its slightest contravention. ${ }^{93}$ In this respect, "subjective" rights (if it is possible to use the term "subjective right", which has traditionally been regarded as conferring a prerogative upon individuals, ${ }^{94}$ in connection with the rights of mankind that concern global interests) are more effective than the mere objective rules dealing with environmental protection, peace and development. All the more so given that the rights of mankind are of a collective nature, ${ }^{95}$ and thus those who seek to avail themselves of the above rights on behalf of mankind do not have to prove, from a theoretical point of view, that they have been individually harmed. In this context, to quote the example of petitions filed by Inuit and then the Athabaskan peoples with the Inter-American Commission on Human Rights, ${ }^{96}$ if the rights of mankind could have been invoked as a supplement to human rights, those petitions had been dealt with quite differently. Moreover, where a subjective right is recognized, a whole series of obligations derive from it. In other words, these obligations are no longer dependent on their incorporation into a specific text, but they are infinite in some way or at least as numerous as they may be necessary for the realization of the right concerned. The recognition of the rights of mankind thus leads to an extension of the scope of obligations.

While the draft Declaration rests on this "natural" dynamics existing between legal rights and duties, the decision was also made to set forth in the above Declaration the duties towards mankind. Indeed, it was established that " $[t]$ he present generations have a duty to guide scientific and technical progress towards the preservation and health of humans and other species" $" 97$ or

93 CARBONNIER, Jean. Flexible droit. 8. ed. Paris: LGDJ, 1995. p. 150.

94 See Cornu Gérard, Vocabulaire juridique, $8^{\text {th }}$ ed., 2000, item «Droit ». See also BERGEL Jean-Louis, Théorie générale du droit, Paris, Dalloz, 2012, $5^{\text {th }}$ edition, p. 39. P As a reminder, the definition of subjective rights is uncertain: for some authors, subjective rights are defined by the recognition of the power of will; for others, subjective rights are legally protected interests (Ihering).

95 See above

96 See above.

97 Article 14 of the Draft Universal Declaration of Rights of Mankind in the Annex to this document. that "the principles, rights and duties proclaimed in this Declaration should serve as a basis for learning lessons, raising awareness and taking further action for their actual implementation". ${ }^{98}$ Contrary to what prevails in the Universal Declaration of Human Rights, ${ }^{99}$ the recognition of rights does not lead to "a retraction of duties". ${ }^{100}$ This decision is explained both by reasons of legal policy and legal technique. From a legal policy perspective, the decision was motivated by the concern to account for different cultures. Indeed, while for the modern Western world, man is defined by "their constitution as an individual who must be endowed with rights", in other cultural traditions man can only be conceived as "a being integrated into communities and defined more in terms of their duties than their rights". ${ }^{101}$ From a more technical point of view, it should be recalled that if rights are always accompanied by obligations or duties, the opposite is not necessarily true. While rights are of a bilateral nature and involve reciprocity, duties, on the other hand, can be unilateral, non-reciprocal and autonomous. ${ }^{102}$ Thus, the duty to guide scientific and technical progress towards the preservation of species, ${ }^{103}$ in particular, does not lead to a right corresponding to that duty. Furthermore, duties can present an added value in relation to a given right: they "indicate more than a specific right as they are basically placed at a general level, that is, beyond the calculation of equivalences between concrete rights and duties". ${ }^{104}$ Therefore, duties cannot be reduced to the corresponding obligations. Finally, on a purely practical level, the reference to duties is likely to increase the effectiveness of the

98 Article 15 of the Draft Universal Declaration of Rights of Mankind in the Annex to this document.

99 In the Universal Declaration of Human Rights, the establishment of duties is limited to just one article (Article 29).

100 BRAGA, Valeschka. La délicate question de l'équilibre entre droits et devoirs en France. Available in: <http://www.droitconstitutionnel. org/congresParis/comC8/BragaTXT.pdf>. Access in: 24 fev. 2016. 101 ROULAND, ano Apud BISSONNETTE, Alain. L'actualité de la Déclaration universelle des droits de l'homme. Revue québécoise de droit international, v. 8, n. 1, 1993-1994. p. 55. On this respect, see for instance, Art. 27 et seq. of the African Charter on Human and Peoples' Rights (Nairobi, 27 June 1981), but also Arts. 29 et seq. of the American Declaration of the Rights and Duties of Man (Bogota, Colombia, 1948).

102 DELMAS-MARTY, Mireille. Vers une communauté de valeurs? Les droits fondamentaux. Seminar held at the Collège de France, 2008. Available in: <http://calenda.org/194353>. Access in: 23 mar. 2017.

103 Art. 14 of the Draft Universal Declaration of Rights of Mankind in the Annex to this document.

104 Braga Valeschka, «La délicate question de l'équilibre entre droits et devoirs en France », op. cit. 
rules enshrined in the Draft Declaration. Indeed, while rights are attributed to mankind, which may appear ethereal, ${ }^{105}$ duties, by contrast, must be implemented by well-identified entities such as States. The recognition of these duties thus makes it possible to anchor the Draft Declaration in reality.

The Draft Declaration specifies the list of debtors of duties towards mankind: ${ }^{106}$ while States, as primary subjects of international law, have primary responsibility in this matter, international organizations, enterprises, in particular multinational corporations, non-governmental organizations, peoples, local authorities and individuals are also targeted. This multiplicity of debtors contributes to explain the choice of using, except for exceptional cases, ${ }^{107}$ the term "duty" rather than "obligation". The reference to "duties" allows for a broad spectrum of stakeholders to be targeted (for instance, transnational corporations), while the notion of obligation could have limited the debtors to subjects of public international law, in particular to States. Undoubtedly, the notion of duties has more of a moral connotation than that of obligations. That does not mean, however, that those duties cannot have a legal dimension: the boundaries between morality and law are not hermetic and the moral nature of a norm is by no means incompatible with its legal character. On the contrary, recognition of a moral obligation is often a "step in the evolution of public awareness". ${ }^{108}$ Certain rights, in particular human rights, have a strong moral

105 On the representation of mankind, see infra (II).

106 See the preamble of the Declaration: "Considering the special responsibility of present generations, especially the States that hold primary responsibility in this area, but also that of peoples, intergovernmental organizations, corporations, including multinationals, non-governmental organizations, local authorities and individuals". An initial version of the text established as follows: "Considering that the duties towards mankind must be complied with by the present generations...". The term « responsabilité » ("responsibility") has finally been preferred to the exclusion of the term "devoir" ("duties"), initially proposed because of its broader scope: this term "responsabilité" ("responsibility") goes beyond the legal responsibility stricto sensu so that it covers the role played by actors other than States and international organizations (businesses in particular) and whose actions are governed by soft law. The concept of responsabilite (responsibility) can be understood here in the sense of accountability.

107 See Article 14 of the Draft Universal Declaration where the term "duty" rather than "obligation". The term duties was chosen instead of obligations insofar as rules of positive law concerning this field already exist.

108 WEISS, Edith Brown. Justice pour les générations futures: droit international: patrimoine commun et équité intergénérations. Paris: Éditions Sang de la terre, Unesco, 1994. p. 97. dimension, which in no way prevents them from having legal effects.

Mankind as a whole is the beneficiary of the duties enshrined in the draft Declaration. The concept of "duties towards mankind", used in this Draft Declaration, is not entirely new, as the Inter-American Convention on Human Rights itself establishes in its Article 32 that "[e]very person has responsibilities ["devoirs" (duties) in the French version] to [...] mankind". ${ }^{109}$ Similarly, in accordance with the Preamble to the Charter of Fundamental Rights of the European Union, the enjoyment of the rights recognized in this text "entails responsibilities and duties with regard to [...] the human community and to future generations". These are duties towards mankind rather than duties of mankind. In other words, they are to be complied with by the present generation, in particular by the international community, ${ }^{110}$ rather than by future generations that are included in the notion of mankind. Therefore, what has sometimes been referred to by means of a terminological shortcut as "duties of mankind" 111 are, in fact, "the duties of the present generation towards mankind", in particular vis-à-vis the future generations. Responsibility is thus not only of an intragenerational nature, but also of intergenerational one. There remains, however, the question of determining who may make a claim on behalf of mankind in case of violation of these rights.

\section{A United Mankind and a Plural MANKIND: INSTITUTIONAL PERSPECTIVES FOR the Draft Declaration}

Reference to mankind in a legal context is sometimes considered as a metaphor. Being described as

109 Convention adopted on 22 November 1969, in San Jose, Costa Rica. The Inter-American Court of Human Rights considers, however, that only States can be held responsible under the Convention to the exclusion of physical persons.

110 On the distinction between "humanité" ("mankind") and "international community", see LE BRIS, Catherine. L'bumanité saisie par le droit international public. Paris: LGDJ, 2012. p. 35.

111 LE BRIS, Catherine. Une déclaration sur les droits de l'humanité: avancée ou simple slogan? Le Huffington Post, 2015. Available in: <http://www.huffingtonpost.fr/catherine-le-bris/declaration-droits-humanite-avancee-ou-slogan_b_6735426.html>. Access in: 24 fev. 2015): in January 2015, the President of the French Republic François Hollande made reference to "duties of mankind" (devoirs de l'humanité), giving rise to some terminological hesitation. 
a "ghost" holder, ${ }^{112}$ mankind would be nothing more than a legal fiction conceived to ensure the protection of values or the transmission of goods. ${ }^{113}$ The question remains, however, as to who can speak on behalf of mankind. ${ }^{114}$ That question was purposefully dealt with only in an indirect manner in the Draft Declaration: pursuant to Article 16 "[a]ll States are under the obligation to ensure the effectiveness of the principles, rights and duties proclaimed by this Declaration, including through the organization of mechanisms to ensure their full observance". ${ }^{115}$ In other words, while the Declaration establishes the principle concerning the effectiveness of the rights of mankind, it leaves it to the States to decide how to ensure its application. Consequently, two options are left to the States: the first one, which is of a prospective nature, consists of endowing mankind with a centralized representation (A); the second one, of a more actual nature, is adapted to the structure of international society and involves the implementation of the rights of mankind by the subjects and stakeholders of international law (B).

\subsection{United Mankind: A Supranational Institution as the Custodian of Rights of Mankind}

Historically, there has always existed an ideal of a united mankind, the so-called, civitas maxima. ${ }^{116}$ This ideal serves as a basis for both legal scholarly writings and positive law. Based on what is known in national legal orders, lawyers tend to turn, quite spontaneously, to a model patterned after a united mankind represented by an institution of a centralized nature in order to address issues concerning rights of mankind. Although this model may, at first glance, seem utopian, it is the one that was used in the field of the law of the sea, in particular when dealing with issues concerning the

112 MATHIEU, Bertrand. Génome humain et droits fondamentaux. Paris: Economica, 2000. p. 92.

113 DARDOT Pierre; LAVAL, Christian. Commun: essai sur la révolution au XXIème siècle. Paris: La découverte, 2014. p. 40. For an opposite opinion, see TERRÉ, François. L'humanité, un patrimoine sans personne. In: ARDANT, Philippe. Droit et politique à la croisée des cultures. Paris: LGDJ, 1999. p. 341 : 'La gestation de l'humanité en tant que personne titulaire d'intérêts juridiquement protégés [...] se réalise lentement."

114 KISS, Alexandre Charles. La notion de patrimoine commun de l'humanité, RCADI, v. 175, 1982. p. 236.

115 No underlining in the original version of the text.

116 TASSITCH, Georges. La conscience juridique international, RCADI, v. 65, 1938. p. 311.
Area ${ }^{117}$ which is common heritage of mankind, having led to the creation of the International Seabed Authority. Pursuant to the terms of the Convention on the Law of the Sea, [a]ll rights in the resources of the Area are vested in mankind as a whole, on whose behalf the $\mathrm{Au}-$ thority shall act". ${ }^{118}$ Furthermore, the Authority shall, in particular, ensure that the activities carried out in the Area do not pollute the marine environment, including the coastline. ${ }^{119}$

In the event of damage to the Area or the marine environment, it is entirely conceivable that the Authority would claim compensation: according to the opinion of the International Tribunal for the Law of the Sea, ${ }^{120}$ even if there is no express provision in the Convention, the Authority is implicitly authorized to do so insofar as it acts "on behalf" 121 of mankind. Therefore, in such a case, the Authority could refer the matter to the Seabed Disputes Chamber of this Tribunal on the basis of the Convention on the Law of the Sea, in particular pursuant to its Article 187(b)(i). ${ }^{122}$

The question remains as to whether it would be possible to generalize this institutional model for it to be used as a mechanism for the enforcement of the rights of mankind. It should be stated that such an idea has in fact been advocated before. It was proposed in particular to extend this model to other areas of environmental protection. In 1989, the States signatories to the Declaration of The Hague on the Protection of the Atmosphere, recognizing that "climate change" is "a common concern of mankind", called for the establishment of a "new institutional authority" to address climate change. ${ }^{123}$ In the same vein, it was proposed that an

117 See Art. 1(1) of the United Nations Convention on the Law of the Sea: "Area" means the "seabed and ocean floor and subsoil thereof, beyond the limits of national jurisdiction."

118 See Arts. 137(2) and 153(1) of the Convention on the Law of the Sea.

119 See Art. 145 of the Convention on the Law of the Sea.

120 INTERNATIONAL TRIBUNAL FOR THE LAW OF

THE SEA. Responsibilities and obligations of States sponsoring persons and entities with respect to activities in the Area, 2011, Case n. 17, para. 180. Available in: <https://www.itlos.org/en/cases/list-of-cases/caseno-17/>. Access in: 23 mar. 2017.

121 See Art. 137(2) of the Convention on the Law of the Sea.

122 See also Article 37 of Annex VI to the Convention on the Law of the Sea. See, on this matter, BEURIER, Jean-Pierre. L'Autorité internationale des fonds marins, l'environnement et le juge. Vertigo, special edition 22, September 2015. Available in: $<$ https://vertigo. revues.org/16169>. Access in: 23 mar. 2017.

123 Declaration on the Protection of the Atmosphere, The Hague, 11 March 1989 (Doc. NU A/44/340). 
international authority should be created to promote the protection of genetic resources ${ }^{124}$ bearing in mind that the preservation of biological diversity is also referred to as a "common concern of humankind". ${ }^{125}$ Moreover, the establishment of a single global government representing humanity as a whole has often been considered and those jurists having put forward such a proposal are more numerous than might be expected. According to Professor Albert de Geouffre de la Pradelle, there is an urgent need to establish "an institutional community authority of a supranational nature capable of endowing mankind with the means to realize its implicit competencies". ${ }^{126}$ More recently, it has also been argued that "even if it might seem utopian in the short term, the establishment of a government representing mankind will become a pressing need in the long term". ${ }^{127}$ If these proposals were implemented, mankind would become a subject of international law, whereas at present it is only a passive subject, that is, it has rights but, given its lack of representation, except for exceptional cases, ${ }^{128}$ has no capacity to exercise them. From a legal perspective, granting mankind legal personality is quite conceivable: legal personality in law is largely of a fictitious character and if it was possible to have recourse to this technique to "optimize a market process (commercial companies), "to institutionalize political power" (States and local authorities) or "to assert collective interests (associations)", ${ }^{129}$ it is not incoherent to consider that mankind may be conferred legal personality. Fur-

124 KLEMM, Cyril de. Le patrimoine naturel de l'humanité. In: Dupuy, Renâe Jean. L'avenir du droit international de l'environnement, colloque de l'Académie de droit international de La Haye, 12-14 November 1984. The Hague: Martinus Nijhoff Publishers, 1985. p. 142 et seq. 125 Preamble of the Convention on Biological Diversity of 5 June 1992.

126 GEOUFFRE DE LA PRADELLE, Paul de. Une idée qui prend corps: la protection internationale de l'humanité. Aix-en-Provence: Presses universitaires d'Aix-Marseille, 1979. p. 103. See also DEL VECCHIO, Giorgio. Humanité et unité du droit: essai de philosophie juridique. Paris: Librairie générale de droit et de jurisprudence, 1963. p. 263. "L'acceptation d'un ordre supranational est une nécessité catégorique qui ne peut être éludée ni soumise à l'approbation de qui que ce soit". "Recognition of a supranational legal order is an imperative need that can neither be avoided nor subjected to the approval of any person or institution".

127 PAQUEROT, Sylvie. Le statut des ressources vitales en droit international: essai sur le concept de patrimoine commun de l'humanité. Bruxelles: Bruylant, 2002. p. 241.

128 See above the case concerning International Seabed Authority. 129 SOHNLE Jochen. La représentation de la nature devant le juge: Plaidoyer pour une épistémologie juridique du fictive. Vertigo, n. 22, sep. 2015. Available in: <https://vertigo.revues.org/16343>. Access in: 23 mar. 2017. thermore, in the Draft Declaration ${ }^{130}$ it is proposed on an optional basis that legal personality be recognized in favor of mankind. However, if this option were chosen, it would be more of a symbolic than a normative nature. Indeed, international legal personality does not derive from its recognition in an legal instrument but from the effective granting of rights and the real capacity to exercise them: "Even if a legal order establishes a rule stating that "X is subject of law", $\mathrm{X}$ would not become a subject of law if that legal order did not grant at least one right or obligation in favor of X'. ${ }^{131}$ Although it is possible, from a legal perspective, to confer legal personality on mankind, such recognition would require, from a political viewpoint, that a certain number of precautions be taken. Firstly, the political unity of mankind, or at least its political construction, appears to be a prerequisite for its recognition as a legal person. The creation of the League of Nations and the subsequent establishment of the United Nations were, in turn, the results of the concern to protect humanity in a universal framework. However, in spite of encouraging progress and the conclusion of a charter that may resemble a constitution, ${ }^{132}$ this organization remains an instance where the differing interests of sovereign States clash. Secondly, special attention should be given to the representativeness of this institution, which would be responsible for embodying the interests of mankind in its entirety: where collective rights are recognized to any group whatsoever, "the question as to who speaks on behalf of whom must always remain open". ${ }^{133}$ This analysis remains especially valid in relation with the establishment of a universal subject that would be responsible for the protection of the rights of mankind, a kind of "global Leviathan"134 that might run counter to hegemonic aspirations.

Moreover, other alternatives are possible. Thus, the idea of a global and/or international environmental organization, more in line with the structure of classical

130 LEPAGE CORINNE ET EQUIPE DE RÉDACTION. Déclaration universelle des droits de l'bumanité, rapport à l'attention de Monsieur le Président de la République. 2015. p. 44. Available in: <http:// www.ladocumentationfrancaise.fr/var/storage/rapports-publics/154000687.pdf>. Access in: 23 fev. 2016.

131 BARBERIS, Julio A. Nouvelles questions concernant la personnalité juridique international. RCADI, v. 179, 1983. p. 169.

132 See the Charter of the United Nations of 26 June 1945.

133 ROULAND, ano Apud BISSONNETTE, Alain. L'actualité de la Déclaration universelle des droits de l'homme. Revue québécoise de droit international, v. 8, n. 1, 1993-1994. p. 55.

134 DELMAS-MARTY, Mireille. Trois défis pour un droit mondial. Paris: Éditions du Seuil, 1998. p. 92. p. 173. 
international law than with the project of a global government, might emerge from its "winter slumber". ${ }^{135}$ Naturally, such an organization, which is confined to a specific field, would have a more limited scope. Furthermore, if that organization were of an international character rather than a supra-State or supranational nature, it could not claim to embody mankind. However, it could act on its behalf, be its representative, in particular in order to advocate the right of mankind to the environment. This could be complemented by the establishment of a global and/or international environmental Court. In this regard, the Draft Declaration contains, as an optional proposal, a provision on the establishment of an "International Criminal Tribunal for the Environment and Health". ${ }^{136}$ Such a perspective is not utopian: the draft agreement on climate negotiated at the COP21 proposed, on an optional basis, the creation of an "International Tribunal of Climate Justice" that would address cases of non-compliance with commitments undertaken by developed-country Parties. ${ }^{137}$ While this option was ultimately not adopted in the Paris Agreement, the fact that it was proposed in the framework of a draft treaty (and that it was maintained throughout the pre-negotiations phase that took place in Bonn) is, in itself, a step forward.

\subsection{Plural mankind: decentralized exercise of the rights of mankind within the international community}

Currently, international society has neither a legislative nor an executive nor a judicial branch at the service

135 BEURIER, Jean-Pierre. L'Autorité internationale des fonds marins, l'environnement et le juge. Vertigo, special edition 22, September 2015. Available in: <https://vertigo.revues.org/16169>. Access in: 23 mar. 2017. On this issue, see Also BEDJAOUI, Mohamed. L'humanité en quête de paix et de développement: cours général de droit international public. RCADI, v. 325, 2006. p. 339 et seq.

136 LEPAGE CORINNE ET EQUIPE DE RÉDACTION. Déclaration universelle des droits de l'bumanité, rapport à l'attention de Monsieur le Président de la République. 2015. p. 45. Available in: <http:// www.ladocumentationfrancaise.fr/var/storage/rapports-publics/154000687.pdf>. Access in: 23 fev. 2016.

137 See the Draft agreement and draft decision on work streams 1 and 2 of the Ad Hoc Working Group on the Durban Platform for Enhanced Action of 4 December 2015 (Art. 11, option 2): “An International Tribunal of Climate Justice is hereby established to address cases of non-compliance with the commitments of developed country Parties on mitigation, adaptation, provision of finance, technology development and transfer, capacity-building, and transparency of action and support, including through the development of an indicative list of consequences, taking into account the cause, type, degree and frequency of non-compliance." of mankind. ${ }^{138}$ Nevertheless, given that nature abhors a vacuum, "the instinctive efforts of mankind to meet the need for solidarity [...] emerge spontaneously from inter-State relations: ${ }^{139}$ the functions that should be performed by the bodies of the mankind community are then carried out by "faster, more straightforward and decisive processes than those that take place in our local and hierarchical societies that are organized on the basis of the specialization of tasks". ${ }^{140}$ In the absence of institutions representing mankind, it is the States that protect the interests of mankind and its rights. As a result of the "functional duplication" technique, where States act on their own account, they act, at the same time, on behalf of the mankind community, as described by theory developed by the French Professor Georges Scelle. While in the assumption of the aforementioned government of mankind, the representation of the entity "mankind" itself is brought into question (the government embodying mankind is, at the same time, its organ, therefore, there is only one legal person), in the case of functional duplication, States ensure the representation of the interests of mankind (two legal entities intervene in this assumption). This is the reason why it is possible to characterize States as being the representatives of mankind. Whenever a State identifies, for example, items for their inclusion in the World Heritage List or ensures compliance with environmental rules on its territory, acts like a "superintendent ("intendant") of mankind". ${ }^{141}$

In case of State interference invoking the rights of mankind (humanitarian, ecological, cultural interference, etc.), such a situation could be legitimately described as a "functional triplication" 142 of acts carried out by a State. Indeed, in that case, the State concerned acts theoretically on behalf of another State and at the same

138 For a more detailed analysis of this issue, see LE BRIS, Catherine. L'bumanité saisie par le droit international public. Paris: LGDJ, 2012. p. 409 et seq.

139 SCELLE, Georges. Le droit constitutionnel international. In: PFISTER, Christian; DUQUESNE, Joseph. Mélanges R. Carré de Malberg. Paris: Edouard Duchemin, 1977. p. 514.

140 SCELLE, Georges. Le droit constitutionnel international. In: PFISTER, Christian; DUQUESNE, Joseph. Mélanges R. Carré de Malberg. Paris: Edouard Duchemin, 1977. p. 512.

141 CHARPENTIER, Jean. L'humanité: un patrimoine mais pas de personnalité juridique. In: PRIEUR, Michel; LAMBRECHTS, Claude. Les homes et l'environnement : quels droits pour le vingt-etunième siècle? Études en hommage à Alexandre Kiss. Paris: Frison Roche, 1998. p. 19.

142 SCELLE, Georges. La notion d'ordre juridique. Revue du droit public et de la science politique en France et à l'étranger, 1944. p. 100. 
time on behalf of mankind. In practice, however, the interfering State also acts on its own account as it is often case that that State has its own interests in the matter in question... ${ }^{143}$

This decentralized protection of the rights of mankind is also present in case of litigation. In its advisory opinion of 2011 on Responsibilities and obligations of States sponsoring persons and entities with respect to activities in the Area, the International Tribunal for the Law of the Sea provided an essential clarification in this regard. It held that in the event of damage to the common heritage of mankind or damage to the marine environment, "each State Party [to the Convention on the Law of the Sea] may [...] claim compensation in light of the erga omnes character of the obligations relating to preservation of the environment of the high seas and in the Area". ${ }^{144}$ Obligations referred to as "erga omnes" are those obligations binding "any State to the international community as a whole", ${ }^{145}$ paving the way for the exercise of the "actio popularis". The rights of mankind constitute the basis of this type of obligation: as Judge Weeramantry pointed out, by taking into account "the greater interests of humanity" and "planetary welfare", "we enter the arena of obligations which operate erga omnes rather than inter partes". ${ }^{146}$ In the aforementioned opinion, the International Tribunal for the Law of the Sea makes reference to Article 48, paragraph 1 of the Draft Articles of the International Law Commission on Responsibility of States for Internationally Wrongful Acts ${ }^{147}$ according to which: "Any State other than an injured State is entitled to invoke the responsibility of another State ... if: (a) [t]he obligation breached is owed to a group of States including that State, and is established for the protection of a collective interest of the group; or (b) [t]he obligation breached is owed to the international community as a whole." The Tribunal careful targeted not only the case where

143 LE BRIS, Catherine. L'bumanité saisie par le droit international public. Paris: LGDJ, 2012. p. 447 et seq.

144 International Tribunal of the Law of the Sea, Advisory Opinion of 1 February 2011 op.cit, para.180.

145 SALMON, Jean. Dictionnaire de droit international public. Bruxelles: Bruylant, 2001. p. 368.

146 Separate opinion of Vice-President Weeramantry in the Gabčíkovo-Nagymaros Project (Hungary/Slovakia) judgment, ICJ Reports 1997, p. 118

147 Draft Articles of the International Law Commission on Responsibility of States for Internationally Wrongful Acts, adopted by the General Assembly of the United Nations in its resolution 56/83 of 12 December 2001. there is a treaty (the case of erga omnes partes obligations referred to in paragraph (a), but also the case where, in the absence of a treaty, the obligation derives from a customary rule (the case of the erga omnes obligations referred to in paragraph (b), providing the holding of the Court with a broader scope.

While it is authoritative, the draft Articles of the International Law Commission is still only a soft law instrument. Furthermore, the question arises as to whether States would resort to this rules in the event that they were recognized. The technique of functional duplication (and, as a result, that of functional triplication) has its limitations: it is likely that, torn between their national interests and those of the human race, States will hesitate to file an application with a court or will only do that on a selective basis, which does not seem to be compatible with an effective protection of the rights of mankind. In this context, the recognition of these rights also means that a bigger share should be reserved for civil society in the international legal order. However, this is not due to the fact that that civil society embodies a "sovereign mankind", 148 but because, just like intergovernmental organizations or States, it is an integral part of the legal aspect of mankind and constitutes a counter-power to sovereignty. This interplay of powers and counter-powers is likely to enhance the efficiency and effectiveness of the rights of mankind. In particular, it could be conceivable that civil society be represented within the framework of a future global environmental organization. Likewise, some non-governmental organizations could be granted ius standi to appear before a World Environmental Court in the event that it were established. The rights of mankind imply a democratization of international society and the establishment of a "globalized forum for discussion". ${ }^{149}$ Some initiatives at the national level favor such an approach. Thus, 886 individuals and a foundation (the Urgenda Foundation)

148 Expression forged by Professeur Sandra Szurek: La société civile internationale et l'élaboration du droit international (report). GHÉRARI, Habib; SZUREK, Sandra. L'émergence de la société civile internationale: vers la privatisation du droit international? Paris: Pedone, 2003. p. 67. For an opposite opinion, see the analysis carried out by Professor Falk: in his opinion, the common rights of mankind are the rights of civil society. "The world order between inter-state and the law of humanity: the role of civil society institutions". ARCHIBUGI, Daniele; HELD, David. Cosmopolitan Democracy: an agenda for a new world order. Cambridge: Polity Press, 1995. p. 165 et. seq. 149 JOUANNET, Emmanuelle. L'idée de communauté humaine à la croisée des États et de la communauté mondiale. La mondialisation entre illusion et utopie, Archives de Philosophie du droit, v. 47, 2003. 
filed an application with the Commercial Chamber of The Hague Tribunal to require that the Dutch State be ordered to reduce its greenhouse gas emissions. The application relied both on human rights (in particular, Article 2 of the European Convention on Human Rights) and on environmental law. The Tribunal upheld the applicants' claim on the basis of the duty of care of the "environment and mankind" pursuant to Article 21 of the Dutch Constitution. ${ }^{150}$ This is a decision issued by a court of first instance against which the Government of the Netherlands has lodged an appeal, ${ }^{151}$ but this case has a strong symbolic dimension.

Could the Universal Declaration of the Rights of Mankind also be invoked by everyone before the national courts in the longer or shorter term? As a soft law instrument, this Declaration is not, in itself $\mathrm{f}^{152}$, creating rights that are likely to be directly invoked before domestic courts. However, national courts, as well as international tribunals, could fully rely on this Declaration to interpret binding texts. One of the benefits of soft law is precisely to pave the way for having recourse to hard law and to gain insight into emerging phenome$\mathrm{na}^{153}$. This is, moreover, one of the stated goals of this Draft Universal Declaration of the Rights of Mankind: to follow social, political and environmental developments, contributing in this way to the renewal of the legal protection of mankind and its interests.

Concerning the Universal Declaration of Human Rights of 1948, René Cassin stated that it can be compared "to the vast portico of a temple whose forecourt is formed by the Preamble affirming the unity of the human family and whose foundations are constituted by the general principles of freedom, equality, non-discrimination and fraternity". ${ }^{154}$ But he went on to say that

150 CANAL-FORGUES, Eric; PERUSO, Camila. La lutte contre le changement climatique en tant qu'objet juridique identifié. LexisNexis, n. 8-9, comment 72, August 2015.

151 ABONNEZ-VOUS. La Haye veut faire appel d'un jugement d'un tribunal local sur les émissions de gaz à effet de serre. Le Point International, 2015. Available in: <http://www.lepoint.fr/monde/ la-haye-veut-faire-appel-d-un-jugement-d-un-tribunal-local-sur-lesemissions-de-gaz-a-effet-de-serre-01-09-2015-1960929_24.php>. Access in: 23 fev. 2015.

152 While the Declaration has no binding force, its norms could eventually become customary rules or be enshrined in future conventions: see above.

153 CONSEIL D'ETAT. Les rapports du Conseil d'État: ancienne collection Étude et documents du Conseil d'État, Paris, 2013, p. 91. Available in: <http://www.ladocumentationfrancaise.fr/var/storage/rapports-publics/144000280.pdf>. Access in: 23 fev. 2016.

154 CASSIN, René. La Déclaration universelle et la mise en œuvre "the portico was nothing but a superb facade behind which there is nothing". ${ }^{155}$ Paraphrasing those words, it can be stated that the doors of the Draft Declaration of 2015, which make it possible to enter the temple of the rights of mankind, actually lead somewhere. ${ }^{156}$ This Draft Declaration was conceived as a text of an international nature and, therefore, the General Assembly of the United Nations, in its global capacity, constitutes the "natural instance" for its adoption. However, the legal aspect of mankind is not an issue to be dealt with exclusively by States: civil society is also called upon to take ownership of this Draft Declaration that is already supported by several non-governmental organizations. ${ }^{157}$ Furthermore, given that universal rights begin close to home, ${ }^{158}$ as Eleanor Roosevelt put it, it is important that local authorities also take ownership of this Declaration. In France, some cities, such as Strasbourg, have already taken the initiative to sign it. The rights of mankind are an invitation to circumvent and/or complement the traditional process of law-making. However, given that that law-making process has "not been completed yet, but it is in the process of becoming a reality", ${ }^{159}$ these rights contribute to the evolution of the legal thinking that, albeit becoming increasingly complex, could also be enriched by such a process.

\section{References}

ALLOT, Philip. Reconstituting humanity: new international law. European journal of international law (EJIL), v. 3, n. 2, p. 219- 252, 1992.

ALSTON, Philip. A third generation of solidarity rights: progressive development or obfuscation of internatio-

des droits de l'homme. RCADI, v. 79, 1951. p. 277/278.

155 CASSIN, René. La Déclaration universelle et la mise en œuvre des droits de l'homme. RCADI, v. 79, 1951. p. 279.

156 CASSIN, René. La Déclaration universelle et la mise en œuvre des droits de l'homme. RCADI, v. 79, 1951. "The doors of the Declaration, which make it possible to enter the temple of human rights, should actually lead somewhere."

157 Especially by the Green Cross International.

158 ROOSEVELT, 1958, Apud OFFICE OF THE HIGH COMMISSIONER FOR HUMAN RIGHTS. ABC: Teaching Human Rights: Practical Activities for Primary and Secondary Schools. New York: United Nations, 2004. p. 11 (Doc. NU A/HRC/29/40).

159 DUPUY, René-Jean. L'assistance bumanitaire comme droit de l'homme contre la souveraineté de L'État: assisting the victims of armed conflict and other disasters. Dordrecht: MartinusNijhoff Publishers, 1989. p. 34. 
nal human rights law. Netherlands international law review, v. 24, p. 307-322, 1982.

AMATO, (d') Anthony. Do we owe a duty to future generations to preserve the global environment? American journal of international law (AJIL), v. 84, n. 1, p. 190- 198, 1990.

APOSTOLIDIS CHARALAMBOS, Fritz Gérard; FRITZ Jean-Claude. L'bumanité face à la mondialisation: droits des peuples et environnement. Paris: L'harmat$\tan , 1997$.

BASLAR, Kemal. The concept of the common heritage of mankind in international law. The Hague: Martinus Nijhoff Publishers, 1998.

BEDJAOUI Mohamed. L'humanité en quête de paix et de développement: cours général de droit international public. RCADI, v. 325, 2006.

BROWN-WEIS, Edith. Fairness to Future Generations International Law: Common Patrimony and Intergenerational Equity. Tokyo: United Nations University, 1989.

BROWN-WEIS, Edith. Our rights and obligations to future generations for the environment. AJIL, v. 84, n. 1, p. 198-207, 1990.

CHEMILLIER-GENDREAU, Monique. Humanité et souveraineté, essai sur la fonction du droit international. Paris: La Découverte, 1995.

COCCA, Aldo Armando. Mankind as a new legal subject: a new juridical dimension recognized by the United Nations. In: INTERNATIONAL INSTITUTE OF SPACE LAW. Proceedings of the 13th colloquium on the law of outer space. Davis/California: University of California School of Law, 1971. p. 211-218.

COUPLAND, Robin. Humanity: what is it and how does it influence international law? International review of the Red Cross, v. 83, n. 844, p. 969-989, 2001.

DELMAS-MARTY, Mireille. Global law: a triple challenge. New York: Transnational Publishers, ano.

DELMAS-MARTY, Mireille. La refondation des pouvoirs. Paris: Éditions du Seuil, 2007. v. 3.

DELMAS-MARTY, Mireille. Le pluralisme ordonné. Paris: Éditions du Seuil, 2006. v. 2.

DELMAS-MARTY, Mireille. Les forces imaginantes $d u$ droit: Le relatif et l'universel. Paris: Éditions du Seuil, 2004. v. 1.
DELMAS-MARTY, Mireille. Vers une communauté de valeurs. Paris: Éditions du Seuil, 2011. v. 4.

DUPUY, Pierre-Marie. L'unité de l'ordre juridique international: cours général de droit international public (2000). Boston: Brill Nijhoff, 2002.

DUPUY, René-Jean. Humanité et droit international: mélanges. Paris: Pedone, 1991.

DUPUY, René-Jean. L'bumanité dans l'imaginaire des nations. Paris: Julliard, 1991.

DUPUY, René-Jean. La gestion des ressources pour l'bumanité, le droit de la mer: colloque, La Haye, 29-31 octobre 1981. The Hague: Martinus Nijhoff Publishers, 1982.

JENKS, C. Wilfred. The common law of mankind. London: Stevens and sons limited, 1958.

JONES, Harry W. Law and the Idea of Mankind. Columbia Law Review, v. 62, n. 5, p. 753-772, may 1962.

KISS, Alexandre Charles. La notion de patrimoine commun de l'humanité, RCADI, v. 175, 1982.

KISS, Alexandre. The emergence of mankind as a legal entity. In: ORWELL Colloquy "1984": Myths and realities : documents. Strasbourg: Conseil de l'Europe, 1984.

LE BRIS, Catherine. L'humanité saisie par le droit international public. Paris: LGDJ, 2012.

MAQUEDA, Ricardo. Something more about humanity as subject of law. In: INTERNATIONAL INSTITUTE OF SPACE LAW. Proceedings of the 13th colloquium on the law of outer space, october 4-10, 1970. California: University of California School of Law, 1971. p. 215-218.

MOREAU-REIBEL, Jean. Le droit de société interhumaine et le jus gentium : essai sur les origines et le développement des notions jusqu'à Grotius. CCHAIL, v. 2, p. 485-596, 1950.

NAGY, Boldizsar. Common heritage of mankind : the status of future generations. In: INTERNATIONAL INSTITUTE OF SPACE LAW. Proceedings of the 31th colloquium on the law of outer space. October 8-15, 1988, Bangalore, India, Washington/DC: American institute of aeronautics and astronautics, 1989. p. 319-325.

PAQUEROT, Sylvie. Le statut des ressources vitales en droit international: essai sur le concept de patrimoine commun de l'humanité. Bruxelles: Bruylant, 2002.

PAYOYO, Peter Bautista. Cries of the sea: world inequality, sustainable development and the common herita- 
ge of humanity. London: Martinus Nijhoff publishers, 1997. v. 33.

PETERS, Anne. Humanity as the A and $\{$ Omega $\}$ of Sovereignty. EJIL, v. 20, n. 3, 2009.

STEPHENS, Alan; WALDEN, Raphael. For the sake of bumanity: Essays in honour of Clemens N. Nathan. Leiden: Martinus Nijhoff Publishers, 2006.

TEITEL, Ruti G. Humanity's Law. Oxford: Oxford University Press, 2011.

TOMUSCHAT, Christian. International law: ensuring the survival of mankind on the eve of a new century: general course on public international law. CCHAIL, v. 281, 1999.

TRINDADE, Antônio Augusto Cançado. International law for humankind: towards a new jus gentium (I) et (II), General course of public international law. CCHAIL, v. 316, 2005.

VAN BEERS, Britta et al. Humanity across International Law and Biolaw. Cambridge: Cambridge University Press, 2014.

VARGAS, Diego Uribe. La troisième génération des droits de l'homme. CCHAIL, v. 184, p. 355-376, 1984.

ZICARDI, Capaldo Guilana. The pillars of global law. Burlington: Ashgate Publishing Company, 2008.

\section{Annex 1 - Draft Universal Declaration of the Rights of Mankind (Paris, 25 September 2015)}

1. Recalling that mankind and nature are in danger and that in particular the adverse effects of climate change, the accelerated loss of biodiversity, and the degradation of land and oceans are all violations of human rights and pose threats to the vital interests of present and future generations,

2. Noting that the extreme gravity of the situation, which is a common concern for humankind in its entirety, requires the recognition of new principles, rights and obligations,

3. Recalling its commitment to the principles and rights recognized in the Universal Declaration of Human
Rights, including gender equality, and to the purposes and principles of the Charter of the United Nations,

4. Recalling the Declaration of the United Nations Conference on the Human Environment (Stockholm Declaration, 1972), the World Charter for Nature, New York, 1982, the Rio Declaration on Environment and Development (Earth Charter), 1992, the resolutions of the General Assembly of the United Nations, namely, the Millennium Declaration, 2000, and The Future We Want, 2012,

5. Recalling that this same danger is recognized by the civil society, especially networks of people, organizations, institutions and cities in the Earth Charter 2000,

6. Recalling that mankind, which includes all human individuals and organizations, covering past, present and future generations, and that the continuity of mankind rests on this intergenerational link,

7. Reaffirming that the Earth, home to humanity, constitutes a whole characterized by interdependence and that the existence and the future of mankind are inseparable from its natural environment,

8. Convinced that the fundamental rights of human beings and the safeguarding duties to preserve nature are inherently interdependent, and that the proper conservation of the environment and the improvement of its quality is of vital importance,

\section{Considering the special responsibility of present} generations, especially the States that hold primary responsibility in this area, but also that of peoples, intergovernmental organizations, corporations, including multinationals, non-governmental organizations, local authorities and individuals,

10. Considering that this responsibility reflects particular duties vis-à-vis mankind, and that these obligations are to be fulfilled relying upon just, democratic, ecological and peaceful mechanisms,

11. Considering that recognition of the dignity inherent to mankind and its members constitute the foundation of freedom, justice and peace in the world, 12. Proclaims the following principles, rights and 
obligations and adopts the present declaration:

\subsection{The Principles}

Article 1:

The principle of responsibility, equity and solidarity, which is of intragenerational and intergenerational nature, demands of the human family and in particular of the States to work in a common but differentiated manner to safeguard and preserve mankind and Earth.

Article 2:

The principle of dignity of mankind and its members involves the satisfaction of their basic needs and the protection of their intangible rights. Each generation ensures compliance with this principle in time.

Article 3:

The principle of continuity of the existence of mankind guarantees the preservation and protection of humankind and the Earth, through prudent human activities respectful of nature, particularly of life, human and non-human, taking all necessary measures aimed at preventing any serious or irreversible consequences that may transcend generations.

Article 4:

The principle of non-discrimination against those belonging to a certain generation preserves mankind, particularly future generations and requires that the activities or measures undertaken by present generations do not have the effect of causing or perpetuating an excessive reduction of resources and choices for future generations.

\subsection{The rights of mankind}

Article 5:

Mankind, like all living species, has the right to live in a healthy and ecologically sustainable environment.

Article 6:

Mankind is entitled to a responsible, equitable, inclusive and sustainable development.

Article 7:

Mankind is entitled to the protection of the common natural, cultural, tangible and intangible heritage.
Article 8:

Mankind has the right to the preservation of common goods, especially air, water and ground, and universal and effective access to vital resources. Future generations are entitled to the transmission of the aforementioned goods.

Article 9:

Mankind has the right to peace, in particular the peaceful settlement of disputes as well as to human security concerning environmental, food, health, economic and political issues. This right aims in particular to preserve succeeding generations from the scourge of war.

Article 10:

Mankind has the freedom of choice to determine its own fate. This right is exercised by taking into account the long term, and notably the cycles inherent to mankind and nature, in collective choices.

\subsection{The duties towards mankind.}

Article 11:

The present generations have a duty to ensure respect for the rights of mankind as well as that of all living species. Respect for the rights of mankind and of man, which are indivisible, apply in respect to successive generations.

Article 12:

The present generations, who are guarantors of resources, ecological balance the common heritage and the natural, cultural, tangible and intangible heritage have a duty to ensure that this legacy is conserved and that it be used with caution, and in a responsible and equitable manner.

Article 13:

To ensure the sustainability of life on Earth, the present generations have a duty to put in every effort to preserve the atmosphere and the climatic equilibrium to prevent as much as possible the movement of people related to environmental factors and, failing this, to rescue and protect the affected people.

Article 14:

The present generations have a duty to guide scientific and technical progress towards the preservation of 
humans and their health as well as another species. To this end, they must, in particular, ensure access and use of biological and genetic resources respecting human dignity, traditional knowledge and the preservation of biodiversity.

Article 15:

All States and other subjects, public and private actors have the duty to integrate the long-term and promote sustainable human development. This as well as the principles, rights and duties proclaimed in this Declaration should serve as a basis for learning lessons, raising awareness and taking further action for their actual implementation.

Article 16:

All States are under the obligation to ensure the effectiveness of the principles, rights and duties proclaimed by this Declaration, including through the organization of mechanisms to ensure their full observance. 
Para publicar na Revista de Direito Internacional, acesse o endereço eletrônico www.rdi.uniceub.br ou www.brazilianjournal.org.

Observe as normas de publicação, para facilitar e agilizar o trabalho de edição. 